\title{
Shell samples
}

The altitudes of the sites from which the shell samples were collected were all determined by hand level. To exclude the effect of error caused by the tide, which in this area has an amplitude of about $2 \mathrm{~m}$, the well-developed Balanus line was used as base level. $100-200 \mathrm{~g}$ of shell material were obtained from about $1-2 \mathrm{~m}^{3}$ of marine sand and gravel. The highest shell-bearing sediments were found just over $40 \mathrm{~m}$ a.s.1., whereas no shells were found in the material of the raised beaches at higher altitudes, the highest being at about $100 \mathrm{~m}$ a.s. 1 ., as at Aumat $\left(68^{\circ} 34^{\prime} \mathrm{N}, 52^{\circ} 57^{\prime} \mathrm{W}\right)$ or at Qeqertasugssuk $\left(68^{\circ} 33^{\prime} \mathrm{N}, 51^{\circ} 32^{\prime} \mathrm{W}\right)$. The shell samples from the marine deposits between the present sea level and $40 \mathrm{~m}$ a. s. 1 . should, together with earlier-dated shell samples from the same area (Weidick, $1972 \mathrm{~b}$ ), enable a reconstruction to be made of the land/sea level changes between about 8000 and 4000 B. P. in an area about $100 \mathrm{~km}$ long from west to east, i. e. along a line from the outer coast towards the Inland Ice (see Weidick, 1972a, fig. 5c).

\section{References}

Harder, P., Jensen, A. S. \& Laursen, D. 1949: The marine Quaternary sediments in Disko Bugt. Meddr Grønland 149, 1, 85 pp.

Weidick, A. 1972a: Holocene shore-lines and glacial stages in Greenland - an attempt at correlation. Rapp. Grønlands geol. Unders. 41, 39 pp.

Weidick, A. 1972b: $\mathrm{C}^{14}$ dating of Survey material performed in 1971. Rapp. Grønlands geol. Unders. 45, 58-67.

Department of Geology and Palaeontology, University of Helsinki, Snellmaninkatu 5, Helsinki 17, Finland.

\section{INVESTIGATIONS ON THE NAGSSUGTOQIDIAN BOUNDARY BETWEEN HOLSTEINSBORG AND KANGÂMIUT, CENTRAL WEST GREENLAND}

\section{David Bridgwater, Arthur Escher, David F. Nash and Juan Watterson}

The southern boundary of the Nagssugtoqidian mobile belt was first mapped by Noe-Nygaard \& Ramberg (1961) on the basis of the progressive deformation of a swarm of basic dykes - the Kangâmiut dyke swarm. Field work in 1969 showed this boundary to have an approximate NE-SW strike (Escher et al., 1970). The object of the summer's field work reported on here was to continue the investigations along the Nagssugtoqidian boundary and to study the deformation- 
metamorphism-dyking relationships in the western part between Holsteinsborg and Kangâmiut.

The field work formed part of a joint project involving the University of Liverpool. Transport in the field was supplied by the GGU cutter "A. Kornerup" with Orla Norsk as skipper.

\section{Regional structure}

The structural outline of the area immediately north of the Nagssugtoqidian boundary is relatively simple being characterised by a predominant ENE strike of the gneiss foliation, dips of about $45^{\circ} \mathrm{NNW}$ locally increasing to vertical, and a marked stretching direction generally plunging NNW down dip. South of the boundary between Itivdleq and Kangâmiut no such pronounced structural trend is evident.

\section{Relation between deformation and dyke intrusion}

Earlier observations from the Søndre Strømfjord area to the east showed that the intrusion of the Kangâmiut dyke swarm took place during, or just after the first Nagssugtoqidian ENE shear movements (Escher et al., in press).

This has now been confirmed in the Itivdleq area, where the Kangâmiut dykes were intruded along early Nagssugtoqidian (Nag. 1) shear planes striking ENE to $\mathrm{E}$. The dykes here are mostly undeformed and unmetamorphosed. Locally they display typical synkinematic shapes and internal foliation.

The early Nagssugtoqidian deformation was locally accompanied by brittle movements causing the formation of ultra-mylonites and pseudotachylites. North of Itivdleq the continuing Nagssugtoqidian movements (Nag. 2) deformed and metamorphosed the dykes into strongly sheared amphibolites. Simultaneously a new foliation and lineation was formed in the gneisses, sub-parallel to the Nag. 1 foliation and lineation. In many places new pseudotachylites can be seen, formed during or after the Nag. 2 deformation, and always following the same ENE trend. Between the Itivdleq area where only Nag. 1 was active and the region to the north where Nag. 2 reworked the Nag. 1 structures, a large "augen" or lacuna of preNagssugtoqidian granulite-facies rock can be observed. The main difference between the Nagssugtoqidian boundary in the Søndre Strømfjord area and in the west, is that in the former the Nag. 2 deformation overlapped considerably the Nag. 1 front, while in the west the Nag. 2 deformation stopped southwards and never reached the boundary of Nag. 1.

\section{Relation between deformation and metamorphism}

The distribution of granulite- and amphibolite-facies assemblages is not considered representative of distinct episodes of metamorphism. Relationships are consistent with the suggestion that the entire area, including that south of the boundary, has remained at "metamorphic" temperatures and pressures throughout 
the period during which Nagssugtoqidian deformation took place and probably for long periods before and after. No changes in crustal temperature distribution necessarily coincided with the onset of Nagssugtoqidian tectonism which affected rocks at temperatures normal at that level of the crust. Granulite- and amphibolitefacies assemblages are essentially contemporaneous. Their distribution is a reflection of probable differences in water content which in turn are the result of varying intensity of deformation. Intensely deformed areas are generally characterised by amphibolite facies assemblages. The Kangâmiut dykes, at the level now seen were intruded into country rocks at "metamorphic" temperatures although they did not necessarily undergo recrystallisation at the time of intrusion.

It is concluded that the Nagssugtoqidian boundary is purely tectonic, imposed at the level now seen, on rocks at a sufficiently deep crustal level for metamorphic temperatures to be more or less constant.

\section{Kimberlitic dykes}

Numerous narrow dykes, up to $3 \mathrm{~m}$ wide, trending predominantly ESE occur in the area between Holsteinsborg and Itivdleq (see fig. 3). Their composition varies from carbonatite to kimberlite and peridotite (see Escher \& Watterson, this report).

A dyke of this swarm collected in 1969 has given a K/Ar age on phlogopitic mica of $584 \pm 18$ m.y. (see Bridgwater, 1971). The dykes locally follow gneiss foliation and they appear to be concentrated in zones of intense Nagssugtoqidian deformation. The possibility that Phanerozoic movements have occurred in the boundary region is now being investigated.

\section{Succession of events}

A succession of geological events in the vicinity of the Nagssugtoqidian boundary has been established as follows:

$?$

Cambrian ?

$\mathrm{K} / \mathrm{Ar}$ ages

1850 m.y. ?
Late fractures with little displacement

Emplacement of dykes of the lamprophyre-carbonatitekimberlite suite

Discordant pegmatites

Transcurrent brittle displacements with pseudotachylites.

Diorite dykes up to $1 \mathrm{~m}$ wide, oriented N-S.

Late

Nagssugtoqidian (?) movements

(Nag. 3)
( Refolding by buckling around NW axes of ENE trending structures, resulting in large open folds.

Brittle over-thrusting from the NNW parallel with earlier ductile over-thrusting. Associated with pseudotachylite veins and breccias and locally open concentric folds with ENE-trending axial surfaces. 
Discordant pegmatites.

Basic norite suite, net-veined, only slightly deformed.

Main

Nagssugtoqidian

deformation

(Nag. 2)

Ductile over-thrusting from the NNW, migmatisation of Kangâmiut dykes. Effects of deformation similar to and displacements in same direction as Nag. 1.

Granites and associated basic rocks.

Emplacement of Kangâmiut dykes. In areas not affected by Nag. 1, striking NNE, elsewhere ENE parallel to Nag. 1 fabric. Locally with typical synkinematic features.

Shear zones parallel to Nag. 1 fabric with formation of pseudotachylites. Displacement sinistral with down-throw to the NNW.

Pegmatites.

Early

Nagssugtoqidian deformation

(Nag. 1)

Ductile simple shear strain. Formation of intense fabrics from isotopic rocks. Direction of displacements partly over-thrusting from NNW and partly transcurrent dextral movements.

Emplacement of E-W basic dykes, sparse.

Regional

high-grade

metamorphism

c. 2800 m.y.
Pre-existing Archaean complex with large areas of homogeneous granitic gneiss and supracrustal formations including marbles, horizons with sillimanite and graphite-bearing schist, pyritic schists, amphibolites, ultrabasic pods and concordant sheets of leucogabbro.

\section{References}

Bridgwater, D. 1971: Routine K/Ar age determinations on rocks from Greenland carried out for GGU in 1970. Rapp. Grønlands geol. Unders. 35, 52-60.

Escher, A., Escher, J. [C.] \& Watterson, J. 1970: The Nagssugtoqidian boundary and the deformation of the Kangâmiut dyke swarm in the Søndre Strømfjord area. Rapp. Grønlands geol. Unders. 28, 21-23.

Escher, A., Escher, J. C. \& Watterson, J. in press: The reorientation of the Kangâmiut dyke swarm, West Greenland. MS submitted to Can. J. Earth Sci.

Noe-Nygaard, A. \& Ramberg, H. 1961: Geological reconnaissance map of the country between latitudes $69^{\circ} \mathrm{N}$ and $63^{\circ} 45^{\prime} \mathrm{N}$, West Greenland. Map Grønlands geol. Unders. 1 (also Meddr Grønland 123, 5).

D. F. N.\& J.W., Jane Herdmann Laboratories of Geology, University of Liverpool, Liverpool 3, $U . K$. 